\title{
AN INTRODUCTION TO TRANSLATION STUDIES: AN OVERVIEW
}

\author{
Intan Pradita \\ Islamic University of Indonesia
}

\begin{abstract}
This study aims to observe the development of translation studies through three concepts of descriptive translation studies; product-based, processbased, and functional-based translation studies. The readers are introduced to some famous translation scholars including their view of translation studies. At the further discussions, this study lets the readers acknowledge the main issues on translation studies, focusing on the debate of equivalence versus variations in intertextual texts analysis. Some tendencies of variations, such as different grammar and sentence structure, diglossia leakage, and pragmatic consideration are also presented to present to what extent variations occur during investigation processes. Therefore, regarding those tendencies, this study is closed by the description of Matthiessen's proposals about points of consideration to construct a parameter to measure meaning variations. This study may help those who are interested to conduct translation researches and help them by giving options of which theories is beneficial to their analysis.
\end{abstract}

Key words: translation studies, variations, intertextual texts analysis

\section{INTRODUCTION}

It is undoubtedly right that translation is important to disseminate information. In line with this premis, the number of translation professionals are getting higher. However, the development of translation studies through researches remains stagnant. In fact, the result of translation researches tend to help human daily life in term of evaluation, designing translator machines, and cultural studies. 
This study tries to observe the development of translation studies by categorizing its concept into product-based, process-based, and functionbased translation studies. By knowing these concept, the writer indirectly persuade the readers to design various translation researches considering minor linguistic until major linguistic analysis in intertextual texts. The opening discussion is on the concept of translation and its debate on equivalency

\section{AN OVERVIEW ON TRANSLATION STUDIES}

\section{Notion on Translation as Translation Studies}

The 1980 was a decade of consolidation for the fledging discipline known as Translation Studies. It was the momentum of defining translation as a theory. Translation has been defined variously by different writers who concern in linguistics. It depends on how they view language and translation. This paragraph tries to explain three views of language and translation, which influence the development of translation studies. Since the dissemination of bibles, translation has played a very important role for information exchange; however, the study of translation as academic purposes was begun in the past fifty years.

As explained by Munday (2004: 3), translation conquers two senses, either translation as a product in which a translator must focus on the concrete product of translation, or as a process on which translation studies centre on the role of a translator in taking the source text (ST) and turning it into the target text in another different language (TT). This is in line with the description of Holmes in his seminal paper, which is mapped by Toury, cited by Munday (2004: 10). 


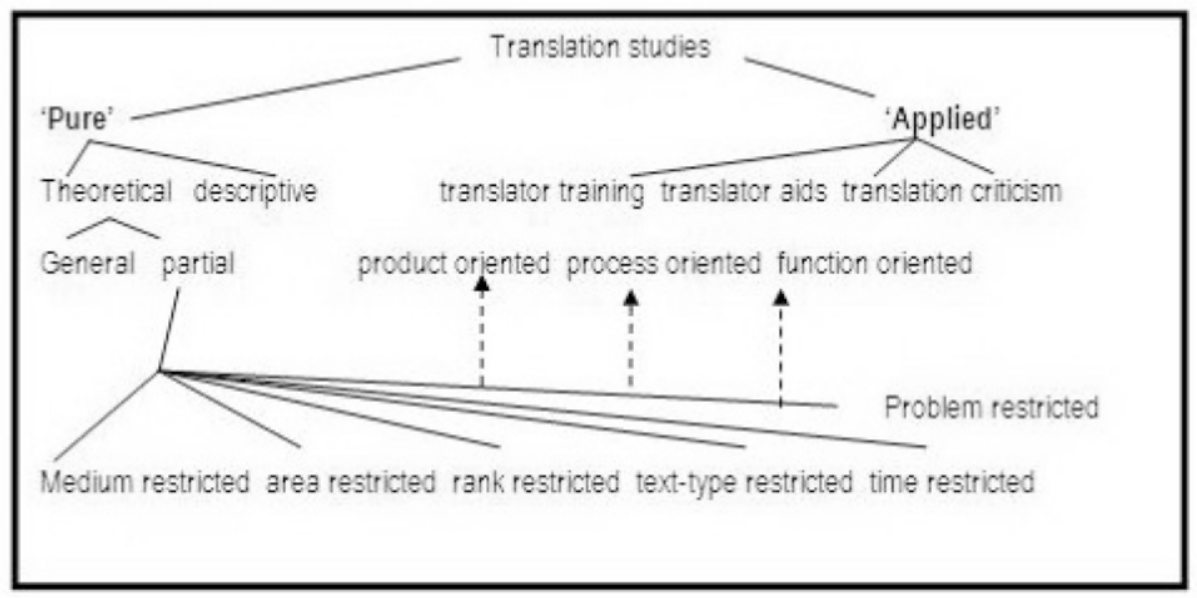

Figure 1. Holmes's 'map' of Translation Studies

Based on the figure above, it is known that indeed translation covers many significant roles. Holmes in his seminal paper, as compiled in The Translation Studies Reader (2004: 184), describes that the two branches of pure translation studies concerning themselves with these objectives can be designated descriptive translation studies (DTS). There are three major kinds of research in DTS, which are distinguished by their focus as product-oriented, function-oriented, and process-oriented.

The area of product-oriented DTS describes two phases, in which the first is individual translations, or text-focused translation description. The second phase is that of comparative translation description, in which comparative analyses are made of various translations of the same text, either in a single language or in various languages. Some translation theories used in this DTS are systemist theories. The next is function-oriented DTS, which is interested not only in the description of translation themselves, but also in the description of their function in the recipient socio-cultural situation. This study concerns more in context rather than texts. Most of translation studies used this type of DTS use functionalist theories. The last is process-oriented DTS, which concerns more with the process or act of translation. Munday (2001: 11) describe that this DTS focus to the psychology of translation, for example a research to find out what happened in the mind of a translator. 


\section{Product-Oriented DTS}

This categorization accommodates some definitions of translation. Newmark in Aveling (2010:5) says that translation is a craft consisting in the effort to replace a non-verbal message or a statement in one language by similar message statement in another language. This definition exactly supports the idea that translation is a product. Another supporting statement is by Margret Amman, cited by Aveling (2010: 5) that 'translation' is when a source text, both verbal and nonverbal has, for certain purpose been used as the model for the production of a text in the target culture.

These two definitions scroll similar agreement that translation must end up as a product on which the content delivers the same messages, not merely the form. The other translation scholars who lean on product-oriented translation studies are Savory and Jacobsen. As explained by Basnett (1980: 14) that Savory defines translation as an 'art', while Jacobsen argues that translation is a 'craft'. Both of scholars agree that translation is near with a unique production for it is said as a 'craft' and an 'art'. An overall conclusion of this view is that translation must have a real product, which are possibly phonemic (interpreting), morphemic, words, group/phrase, clause, and text. This view influences the systemist theory as represented by Halliday, Matthiesen, and Martin. The theory concerns more on the comparative studies on the degree of similarity of each linguistic unit, which is categorized as synchronic study, or the history of translation products during certain period, a diachronic one.

\section{Process-Oriented DTS}

Translation as process-oriented view can be said as the most favorable definitions of translation. Many translation scholars define translation is an act of communication. The most prominent translation expert who is popular for his Bible translation is Nida. Nida and Taber (1982: 12) claims that translation as the process of reproducing in the receptor language to the closest natural equivalent of the source language message.

The first is in the terms of meaning and secondly in terms of style. The term reproducing is highlighted by Nida since it is the ultimate aim in translation. It consists of making a good many grammatical and lexical adjustments. This statement is identical with the statement of Machali (1998: 1) who says that translating is an act of recreating meaning, not that of creating meaning. A good 
translation surely difficult to gain an absolute similarity for each language has its own uniqueness, either grammatical or cultural meaning. The one who translate any documents must consider on the limitation of deriving faithful translation in which an SL text must be the same as the TL text.

Catford (1969: 20) agrees to both of arguments above that translation is the replacement of textual material in the Source Language text by equivalent textual material in the Target Language text. However, this definition seems limited on the use of textual material terms because translation is not only limited to the use of something textual but also untextual material, as described by Roman Jacobson as an intersemiotic translation. Therefore, this definition focuses more on the textual analysis rather than the meaning of a translated text proven by the famous approach of translation' shifts'.

Overall, the most comprehensive definition supporting process-oriented translation is derived by McGuire (1980) via Machali (1998: 1),

Translation is the rendering of a source language (SL) text into the target language (TL) so as to ensure that (1) the surface meaning of the two will be preserved as closely as possible but not so closely that the TL structures will be seriously distorted (McGuire, 1980: 2)

This definition has covered almost all similar ideas presented before, that translation is indeed a process that begun with the prefix re-. It means that translation does not take only once in its process but also twice or more processes. The idea of similarity is also argued as something impossible that the demand of translation as a process is near with making the natural and closest equivalence. Barely is the process of translation demanded to be the same.

\section{Function-Oriented DTS}

This view somehow leads three prominent translation scholars: Reiss, Vermeer, and Nord blush the functional theories of translation. 'Functionalist' in Nord (1997: 1) is defined as focusing on the function or that texts and translations have certain functions. Among the three functionalist theories, skopos theory by Vermeer, Translational Text-Analysis by Nord, and Text Type and Language Function by Reiss, the one who has played a major role in the development of functionalist trend is skopostheorie. Vermeer as explained by Munday (2001: 80) says that the term 'skopos' is the Greek word for 'purpose' or 'objectives'. It was introduced into translation theory in the 1970 s by Vermeer as a technical term for the action of translating and as a purpose of a translation. This definition 
emphasizes that translation must have a reason behind it. Vermeer even gives several basic underlying rules of the theory. Similar with Vermeer, Reiss in Munday (2001: 73) focuses on the ultimate aim, which is initially at systematizing the assessment of translations. Reiss chooses to take text as the concept of equivalence rather than words or sentences. This approach is mostly used to assess literary translation, for readers are the important factor. In line with this, Nord (1997: 22) explains that translation is an act of communication. It means during communication process, both speakers and hearers transfer meaning. The meaning associated with the sign does not need to be the same for both the producer and the receiver. An overall conclusion upon this part is that translation both as a product and as a process must be purposive. Not only does this approach facilitates a helpful analysis of literary texts but also launches the idea of translation training since, again, readers are the key point.

\section{MAIN ISSUES IN TRANSLATION STUDIES: EQUIVALENCE OR VARIATIONS}

Talking about translation will always be related to the concept of equivalence. Although some experts view this as a left-behind theory. However, this term has played a very crucial role towards translation studies for it is the beginning theory to evaluate translation products and translation processes. The definition of equivalence given by many translation scholars is various, that it further becomes an everlasting debate. However, after long discussions, Newmark firstly introduced a basic concept of variations, which is then developed into the theory of Register Analysis. In the last development, it is familiar to mention the new issue, variations.

\section{Equivalence}

The term equivalence must include at least two texts, the SL text and TL text. Some linguists argue that equivalence will never be gained no matter how best the translator is. Some other argues more on the idea of rendering meaning. There are three translation scholars presented in this session. They are Nida, Newmark, and Baker. Equivalence according to Nida in Munday (2001: 41) divides equivalence into two. The first is formal equivalence, which focuses on the message of a text, both in its form and content. The main consideration is the message in the target language should closely match as good as possible to the 
different elements in the source language. This definition concerns more to the structure analysis, which influences strongly in determining grammatical accuracy and correctness. The example is closely presented by the translation in Chapman and Hendry (2008: 7):

Big Mouse got out of bed and opened the bedroom curtains

\section{Tikes Besar bangun dari tempat tidur dan membuka tirai jendela.}

The translation shows that the receptor language is grammatically correct since each element of grammar is exactly in the same number. Each clause in Source Text and in Target Text performs similarity, which means there are no significant meaning alterations. On the other hand, Nida also launches dynamic equivalence via Munday (2001: 42) which focuses on the relationship between target language and message should be the same as that existed between the source language and the message. This form of equivalence is similar to the description by Jacobson in Munday (2001: 36) "there is ordinarily no full equivalence between code-units". Comparing formal and dynamic equivalence, the formal one tends to be hard to achieve. This is because each language in this world does not present the same grammatical accuracy and so do cultural values. Therefore, when there are no equivalent words in the receptor language, formal equivalence tends to be a tense translation. On the other hand, dynamic equivalence presents a wiser point of view that both grammatical and cultural diversities will always occur during the translation process. Therefore, this definition is considered more available.

Separately Baker (1992: 5) categorizes equivalence into several classes. Those are equivalence at word level, above word level, grammatical equivalence, textual equivalence, and pragmatic equivalence. Each of them explores the meaning of single word, a group of words, textual meaning, grammatical, and lexical relationship linked to various parts of text, and on how texts are positioned in communicative situations. Pragmatic equivalence perhaps the only one form of equivalence, which proves that equivalence, will always be affected by many variables such as writers, readers, and cultural context. Moreover, Baker (1992: 6) believes that equivalence can usually be achieved to some extent. Her interesting comment is since a variety of linguistic and cultural factors always influence equivalence, therefore it is always relative.

Similar to Baker, a German linguist, Newmark provides a criticism towards the idea of equivalence. Munday (2001: 44) describes that Newmark 
departs from Nida's receptor-oriented line. However, he believes that successful equivalence effect is not original. Moreover, Newmark (1991: 39) argues that the definition of a good translation is equally problematic. He then provides two new terms, semantic and communicative translation to narrow the gap between emphasis on source and target language, which always remain as the overriding problem in translation theory. Semantic translation is personal oriented one, which believes that inaccuracy is always wrong and the prominent target is a 'true' version of translated text. Besides, communicative translation allows a certain replacement, a stylistic synonymy, and the ultimate target is a 'happy' version or a successful act of translation, (Newmark, 1991: 12). Although these two terms are quite similar to formal and dynamic equivalence, but Newmark still believes that the term of equivalence is hard to achieve.

As an overall conclusion, the term equivalence is firstly introduced by Nida, those are formal and dynamic equivalence. What seems problematic upon this term is its difficulty to be presented in the target text. The variety of grammatical structure and cultural values in each language affects to the either easily achieved or hardly-achieved translation.

\section{Register Variations}

Some linguist believes that measuring inaccuracy in the translated text is easier. Here are presented two interesting argumentations leading to the analysis of variation in the translation studies. The first is from Machali, (1998: 5) who implies that equivalence should not be tempted merely on searching the sameness. It is also unwise to see equivalence from only one tradition of writing, in this case is the cultural approach. Machali suggests a more worthwhile view, which is reexamining equivalence and reevaluating the conditions associated with it by involving more varieties of text. This statement opens a new discussion that there is another way to measure translation products and process, it is through variation. The idea of variation is also launched by Newmark (1991:39),

Admittedly, in translation, inaccuracy, wrongness, is easier to demonstrate than accuracy, rightness (aesthetic as well as cognitive), where there may be competing truths to reflect, and where the ultimate taste factor is likely to blur any single choice of a word.

The statement supports the idea of variation for it is easier to be evaluated. Newmark also believes that there are some subjective variables of a translator that influencee the target language translation. These variables are imposed as the 
causes of variation. Moreover, in his additional statements, Newmark launches the idea of measuring variations, namely the degree of variations. It is implied by Newmark's suggestion to all translators that although equivalence is hard to achieve, it does not mean a translator cannot narrow the degree of variation.

Considering Newark's statement that there are external factors that influence text variations, that of the translators' subjectivity, the register theory is then introduced. Register theory as explained by Eggins (2004: 9) describes the impact of dimensions of the immediate context of situation of a language event on the way language is used. This definition is clear enough to describe that context is an important point in translation.

Halliday and Hasan (1994: 36) state that register is a semantic concept, which can be defined as a configuration of meaning in a particular situational configuration of field, tenor, and mode. This concept is inspired by the idea that texts are situated language, and situated is similar to being instantiation or realization of a language system under contextual constraints, (Steiner, 2004: 11). It is affirmed that a text is always be surrounded by context that are configured through field, mode, and tenor. Tallapessy (2011: 25) explains that field refers to the institutional setting where a language is used; tenor refers to the participants' relationship, and mode refers to the media of communication adopted. Among these three statements, it can be concluded that register is an important feature to analyze translation products, especially in dealing with context as the influential factor in the degree of variations through the lexicogrammar and semantic analysis.

As cited by Eggins (2004: 111) Halliday states that language is designed to accommodate three main functions: a function for relating experience represented in experiential meaning, a function for organizing information as represented in textual meaning, and a function for creating interpersonal relationships as represented in interpersonal meaning. These types of meaning can be related both to context and to lexicogrammar. Moreover, Halliday and Matthiessen (2004: 586) explain their argument upon the relation between lexicogrammar and semantics. It begins with the idea that lexicogrammar makes two fundamental contributions beyond the upper part of grammatical units, the first is the creation of logo genetic patterns, and the second is the marking of cohesion. The term logo genetic patterns are based on instantiation. It is the relationship between an instance and a generalized instance. For example, a news report where the reporter selects verbal 
clause, one after another, until this emerges as a favorite clause type. This patterns that emerges as a text form a temporary system that is specific to texts. However,

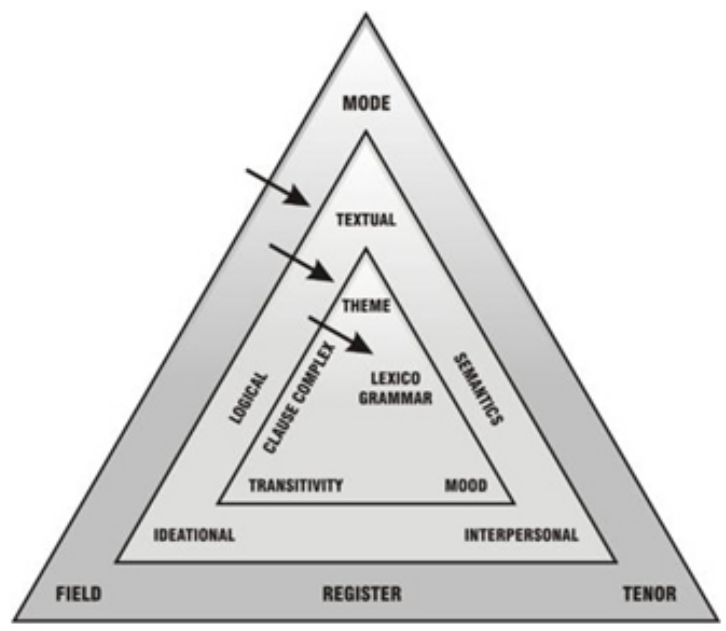

G E N R E

Figure 2. Context, Semantics, and Lexicogrammar 
On further discussion, Matthiessen argues that register shows "one fundamental element of organization of language in context" (1993: 25). He believes that language in context is organized globally along three dimensions. The first is dimension of stratification, which includes orders of symbolic abstraction related by realization. Second in metafunctional diversification, which includes modes of meaning and the last, is potentiality, which covers the dimension from potential to instantial through instantiation, from system to text. As a conclusion, three language factors are symbols, meaning, and instantiation. One good point proposed by Matthiessen is that context has a system and stratification.

By this discussion, variations are more interesting to investigate rather than equivalence because the study on translation is no longer stick on the idea of similarity, which is rarely easy to gain. Variations regard context as the point of investigation.

\section{MATTHIESSEN'S PARAMETER ON REGISTER VARIATIONS}

In some translation researches, the most difficult part is measuring to what extent the variations exist in intertextual texts. Different concept of grammar and sentence structure, diglossia leakage, language variations, and pragmatic consideration may cause the existance of variations. However, the researcher must construct a parameter on how and why we can say the variations in an intertextual text is low or high.

Does 90\% diglossia leakage in Javanese influence register variations when a researcher investigates Bahasa Indonesia-English document? For example the word $i b u$ is previously placed in $\mathrm{H}$ level of diglossia to call only a mother. Since diglossia leakage is occured, it turns into mama in $\mathrm{H}$ level of diglossia and change $i b u$ into a word to call any older woman than us. It runs a question when there is the word mama in Bahasa Indonesia text, should it be translated into $i b u$ or keep it as mama?

Does different system of finite verbs in Bahasa Indonesia and French supports a high degree of variation? Halliday and Matthiessen (2004:116) classify finite into two types, the first is temporal finite verbal operators, and the second is finite modal operators. The one that gives to the Finite, which could be either past, present, or future is temporal finite verbal operators. Separately, finite modal operators anchor the preposition not by reference to time but by reference to 
Modality. Bahasa Indonesia does not have finite by reference to time because it prefers adverbs to emphasize time reference, while French has. To strengthen the idea of constructing a parameter of measurement in register variations, the next discussion emphasizes on how unstable meaning is and how to overcome it.

As explained by Djajasudarma (2009: 10) a word meaning may extend (breadth) which is more extended than the prediction, or get narrow when the meaning of a word is narrower than the whole utterances. For instance, the word girl and girlfriend get narrower meaning, and when it is reversed, the word girlfriend does an extended meaning. By here, the variations of clauses are made by the number of additions or omissions of word.

Larson (1984: 17) provides a mapping of translation continuum. He believes that translations fall on a continuum from very literal, to literal, to modified literal, to near idiomatic, to idiomatic, and then may even move on to be unduly free.

A literal translation makes little sense in English (Larson, 1984: 15). If the source and target language are related, the literal translation is understandable. However, the literal choice of lexical items makes the translation around foreign. For instance, the translation of 'Madame Odette, passenger with destination Doula, is demanded on the telephone' in French, Madame Odette, passenger à destination de Douala est demanded au telephone. The translation seems strange for the meaning is actually Madame Odette gets a phone call.

Different to modified literal translation, Larson explains that it allows translators to usually adjusting the translation enough to avoid real nonsense and wrong meanings, but unnaturalness still remains. This translation creates more variations for some modifications involve less or more grammatical elements. It is similar to idiomatic translations that use natural forms of the receptor language, both in the grammatical constructions and in the choice of lexical items. Larson adds (1984: 16) that a truly idiomatic translation does not sound like a translation. The last part in this continuum is unduly free translation, which is not acceptable for most purposes because the addition in the translated texts is sometimes not the messages in the source text. In other words, unduly free translations consist of too much omissions or additions. The translation continuum is presented in this figure: 


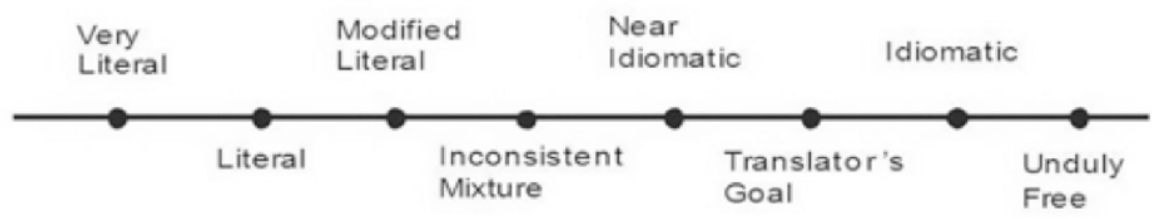

Figure 4. The Translation Continuum by Larson

Knowing that meaning is not constant, Matthiessen's proposal (1993: 244249), that in register, there are three approaches that can prove register variations of intertextual texts is valuable for translation reseachers to consider certain points valuing register variations.

Those are:

1) Probabilistic system with register skewing

It is the way to measure register variations by finding the frequency in one text compared to another one. In the end, the frequency is identified by the dissimilarity of grammar, which is mostly described quantitatively.

2) Partitioned multi-register system with "common core"

It is the way to classify each register based on any possible numbers. For example, zero is for the absence and one is for the presence. The possibility of differentiation can be interpreted qualitatively.

3) Separate register-system

This is the way to classify register and system. It means that if register exists without involving language factors, the register variations can be examined by considering situational context in the text completely

\section{CONCLUSION}

Over the discussion above, there are three points concluded:

1. there are three bases of descriptive translation studies which are productbased, process-based, and function-based translation studies, 
2. in its development, translation studies cover its main issues, equivalence versus variations. The investigation of variations in intertextual texts are interesting for context is deeply concerned,

3. since meaning is not constant, moreover there are certain tendencies of variations such as different grammar system, diglossia leakage, and pragmatic consideration (literal-undully free meaning), therefore a researcher of tranlsation studies must design a parameter to analyze the extent of variations.

\section{REFERENCES}

Aveling, H. (2010). Readings in translation studies. Yogyakarta: UGM Press.

Baker,M. (1992).In other words: a coursebook on translation. London and NewYork: Routledge.

Bassnett, S. (2002). Translation studies. London: Routledge.

Butt, D., et. al. (2001). Using functional grammar: An Explorer?s Guide. Sydney: Macquire University.

Catford, J. C. (1974). A linguistic theory of translation. London: Oxford University Press Inc.

Chapman, J., \& D. Hendry. (2008). Malam yang sangat berisik.(Translated by Hertriani Agustine). Surabaya: Erlangga.

Djajasudarma, F. (2009). Semantik 2: pemahaman ilmu makna. Bandung: Refika Aditama.

Halliday, M.A.K. \& C. Matthiessen. (2004). An introduction to functional grammar: third edition. London: Arnold.

Halliday,M.A.K. \& R.Hasan. (1994). Bahasa, konteks, dan teks: aspek-aspek bahasa dalam pandangan semiotik sosial. (Translated by Asrudin Barori Tou). Yogyakarta: Gadjah Mada University Press.

Larson, M. L. (1984). Meaning-based translation: A guide to crosslanguage equivalence. Lanham: University Press of America.

Matthiessen, C. (1993). Register in the round: diversity in a unified theory of register analysis. In M. Ghadessy. Regsiter Analysis: Theory and Practice (pp 221-292). London and New York: Pinter Publishers. 
Munday, J. (2001). Introducing translation studies: theories and applications. London: Routledge.

Newmark, P. (1991). About translation. Adelide: Multiligual Matters Ltd.

Nida, E., \& C. R. Taber. (1982). The theory and practice of translation. Leiden: United Bible Societies.

Nord, C. (1997). Translating as a purposeful activity: functionalist approaches explained. Manchester: St. Jerome Publishing.

Machali, R. (1998). Redefining textual equivalence in translation (with special reference to Indonesia-English). Jakarta: The Translation Center Faculty of Art - the University of Indonesia.

Steiner, E. (2004). Translated texts: properties, variants, evaluations. Frankurt: Peter Lang. 